\title{
二次元海浜変形の相似則について \\ ON THE SIMILITUDE IN TWO-DIMENSIONAL BEACH CHANGE
}

\author{
伊藤 政博*.土屋 義人** \\ By Masahiro ITO and Yoshito TSUCHIYA
}

\begin{abstract}
The purpose of this paper is to present a scale-model relationship for similarity between full-scale and scale models of two-dimensional equilibrium beach profiles. A similarity comparison between full-scale and small-scale model is made by considering the degree of experimental error. The similitude obtained is graphically shown, and the scale-model relationship is also formulated. It is found that the small-scale relationship agrees with the ones derived from shoreline change, critical water depth of sediment movement, and beach profile.
\end{abstract}

\section{1. 緒 言}

1947 年に Beach Erosion Board ${ }^{1}$ (現在, 米国海岸工 学研究センター) で, 海浜変形の相似則の研究が規則波 を用いた二次元模型実験に基づいて行われた。 その後, 海浜変形の相似則に関して, 理論的あるいは実験的研究 が数多く発表されてきた. 前者では, Le Méhauté2) (1970) が砂の移動量を無次元水理量で表示し，これに 基づいて相似則を求めている. また，底面粗度および縮 尺のひずみ効果を考察して, Kamphuis ${ }^{3)}$ (1972) は底 質の移動に関する時間縮尺を研究し，さらにMogride ${ }^{4)}$ （1974）は底面粗度および境界層厚の効果を考慮した相 似則を提案している.一方, 後者として, Saville ${ }^{5)}$ (1957) および岩垣ら ${ }^{6)}(1961)$ は，波および底質の粒径を Froude 則に従って縮小すると，原型と模型の海浜断面 形状が必ずしも相似にならないことを確かめ, 縮尺効果 の影響を論じた. Paul ら) (1972) および出口ら ${ }^{8)}$ (1976) は，底質の比重を変えて相似則を見出すことを試みた。 また, Dalrymple ら ${ }^{9)}(1970)$ および野田 ${ }^{10)}$ (1978) は,

* 正会員 工修 名城大学助教授 理工学部土木工学科 ( ₹468 名古屋市天白区天白町八事裏山 69-49)

** 正会員 工博 京都大学教授 防災研究所

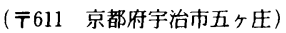

模型の底質として砂を用い，縮尺のひずみが相似性に与 える影響を検討した。ささに，縮尺のひずみのみならず， 底質の粒径および比重を変えた Noda ${ }^{11)}$ (1972) の研究 が発表されている.これらの研究による相似則は，特定 な実験条件では有意であるが，現地海岸を対象としては 十分な検証がなされていない。

本論文では, 海浜変形の相似則を研究する第一歩とし て，二次元海浜変形の相似則を実験的に考察する.その ために,まず, 原型と模型における海浜断面形状の比較・ 照合に必要な実験誤差を考慮した判定基準を予備実験で 求め, 次いで, 原型と模型の海浜変形がほとんど平衡状 態にある場合, 両者が定量的に相似となる条件を見出す. また，こうして求めた相似側と海浜変形の特性を表示す る関係式から導かれる各種相似則との関係についても考 察する.

\section{2. 海浜変形の再現実験における実験誤差}

Chesnutt ${ }^{12)}$ や Smith ら ${ }^{13)}$ は, 実験中の水温変化や造波 水槽内の水位の微小変化が海浜変形に有意な影響を及ほ すことを指摘している。一般に，実験誤差には，（ｉ） 機械誤差, 物理誤差および個人誤差による “系統誤差” (systematic error)，（ii）測定機械の振動および計測 中の光線の不規則な屈折などによる不明確な原因によっ 
て生じる誤差で, 生起の方向ならびに誤差の大きさが まったく不規則な “偶然誤差” (accidental error)，お よび（iii）測定機械の操作，読み取り，記録の段階なよ゙ で生じる “過誤” (mistake) がある ${ }^{14)}$.これらの各誤差 の中で，（i）および（iii）は実験の工夫や熟練によっ て取り除くことが困難である.

本研究では，海浜断面形状を代表する初期汀線からの 汀線移動量（汀線移動量），初期汀線から berm 頂まて の水平距離 (berm 頂の位置)，および砕波特性として汀 線から砕波点までの距離（砕波点の位置）について，そ れぞれの実験誤差（以下，特にことわりのないかぎり偶 然誤差を指す）を定量的に表示し，相似性の判定基準を 定める。

\section{（1）実験 誤 差}

二次元造波水槽内に移動床で一様な初期勾配 $i_{0}$ の海 浜を造り，水槽水平床部の水深 $h$, 波高 $H$ および周期 $T$ などの実験の初期条件をすべて一定として，数回実 験を繰り返した．しかしながら，同一の実験条件で測定 された海浜断面形状は Fig. 1 に示すようにかなり相違す る.この海浜断面形状の相違は，他の実験条件について も同様，波の作用時間の長短にあまり関係なく生じるこ 亡が認められる. そこで, 無次元の汀線移動量 $X_{s l} / L_{0}$, berm 頂の位置 $B_{x} / L_{0}$, および砕波点の位置 $X_{b} / L_{0}$ にも 実験による相違が当然現われるので，これらの実験誤差 を誤差論に従って評価する。

誤差論によれば，誤差の表示法として平均二乗誤差 (mean square error), 確率誤差 (probable error), お よび平均誤差 (mean error) の 3 種類がある. 海浜変形 の実験誤差を誤差論に従って処理するためには，実験の 繰り返し数を十分多くとることが要求される. しかし， この種の実験では，長時間を要し，多くの繰り返し実験 を行うことは難しいので, 繰り返し数を 5 回程度にとよ゙ めた。したがって，本研究では，実験誤差を次式による

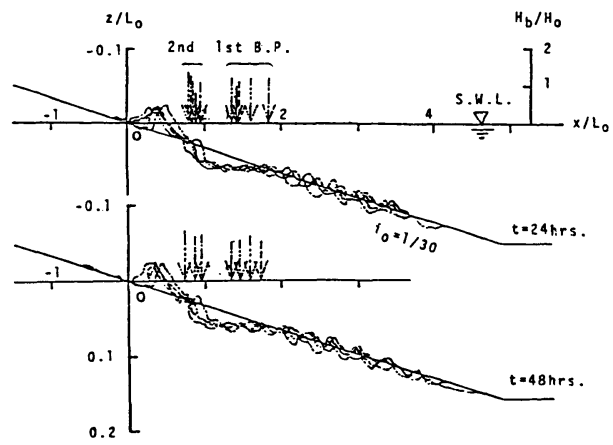

Fig. 1 Experimental error of repeating runs in Run No. 4M-18. Position and height of $\downarrow$-symbol show breaking point and relative height, respectively.
平均誤差 $\varepsilon^{\prime}$ で表わす.

$$
\varepsilon^{\prime} \Delta x= \pm \sum_{i=1}^{n}\left|x_{i}-\bar{x}\right| / n
$$

ここに， $\varepsilon^{\prime} \Delta x$ は実験誤差， $x_{i}$ は繰り返し $i$ 番目の測定 値, $\bar{x}$ は平均値 $\left(\bar{x}=\sum_{i=1}^{n} x_{i} / n\right), n$ は実験の繰り返し回数 である．実験結果の中で，波の作用時間が $t=10 \mathrm{~h}$ 以上 で海浜の変形が比較的安定しているものについて,式(1) で計算した汀線移動量， berm 頂の位置，および砕波点 の位置の実験誤差をそれぞれ $\varepsilon^{\prime} \Delta X_{s l} / L_{0}, \varepsilon^{\prime} \Delta B_{x} / L_{0}$ お よび $\varepsilon^{\prime} X_{b} / L_{0}$ とし，沖波波形勾配との関係で整理する. その結果の一例として, Fig. 2 には汀線移動量の実験誤 差が示してあり，参考までに完全な繰り返し実験ではな いが，Watts ${ }^{15)}$ による波の周期を作為的に変化させたも のや，玉井 ${ }^{16)}$ による beach cusp の三次元平面実験結果 をも含めてある．実験結果の整理に際して，沖波波高 $H_{0}$ と底質粒径 $d$ とその水中比重 $s$ との比, $H_{0} / s d=60$ $\left(s=\sigma / \rho-1=1.65\right.$ の砂の場合, $H_{0} / d \approx 100$ に相当す る值）で，図中の記号の大小を区分し，また，初期汀線 から前進および後退を分類してある．このようにして， プロットした結果のばらつきを包含する線を図中に実験 で示した。 また，同様の方法で求めた berm 頂の位置お よび砕波点の位置の実験誤差の包含線の結果のみがそれ ぞれ砕線および点線で Fig. 2 に併示してある.この図か ら, 汀線移動量と berm 頂の位置の実験誤差の包含線は, その大きさや傾向がよく一致し，砕波点の位置の包含線 の傾向ともよく類似していることが認められる，一方， この図からは, $H_{0} / s d$ (粒径波高比) および $i_{0}$ （初期 浜勾配）が実験誤差に及ぼす影響は見出せない，Fig. 2 における汀線移動量， berm 頂の位置および砕波点の位 置の各実験誤差のばらつきを包含する線を沖波波形勾配 との関係で表わすと，それぞれ次のようになる。

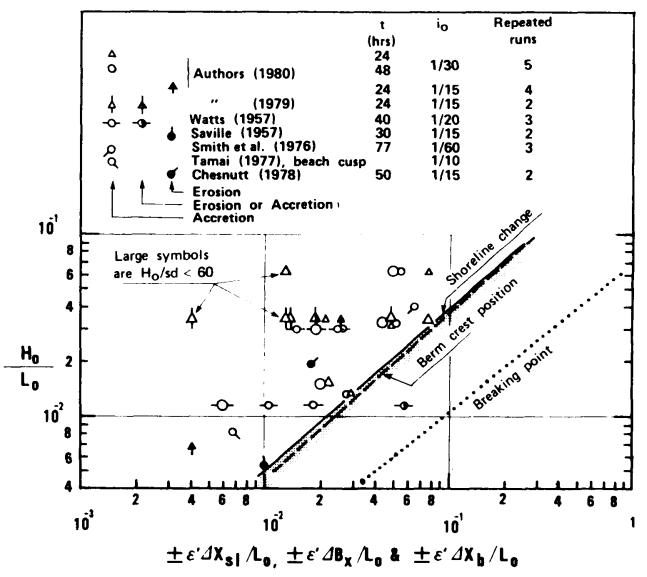

Fig. 2 Experimental errors of shoreline change $\left(\varepsilon^{\prime} \Delta X_{s l} / L_{0}\right)$, berm crest position $\left(\varepsilon^{\prime} \Delta B_{x} / L_{0}\right)$, and breaking point $\left(\varepsilon^{\prime} \Delta X_{b} / L_{0}\right)$. 
$\varepsilon^{\prime} \Delta X_{s l} / L_{0}= \pm 5.7\left(H_{0} / L_{0}\right)^{1.2}$

$\varepsilon^{\prime} \Delta B_{x} / L_{0}= \pm 4.0\left(H_{0} / L_{0}\right)^{1.1}$

$\varepsilon^{\prime} \Delta X_{b} / L_{0}= \pm 27.5\left(H_{0} / L_{0}\right)^{1.24}$

\section{（2）相似性の判定基準}

原型と模型の間で海浜変形の相似性が成立するために は，海底地形，波，および波による底質の移動などの諸 現象がそれぞれ相似之ならなければならない，いま，平 衡状態にある二次元海浜変形を考えるならば，次の諸現 象が相似とならなければならないであろう。すなわち，

(i ) 海浜断面形状

（ii） 漂砂の移動形式と移動限界水深，および岸沖漂 砂量

（iii）砕波点の位置, 碎波高, 砕波形式, 波の遡上高さ, および反射率などの波の諸特性

本研究では，（i ）海浜断面形状に関して, 実験誤差 の中にかくれる砂漣程度の微小な地形変動は相似性の対 象としない，一般に，原型と模型の海浜断面形状が，実 験誤差の範囲内で幾何学的に相似であるならば，（ii ） の現象も大局的に相似性を満足しているものと考えて, （ｉ）の相似性の判定によることにする.（iii）については, 波の諸特性の中で特に砕波点の位置を相似性の判定条件 とする.

以上の観点で, 海浜変形の相似性を次の 3 つに分けて 判定する. 原型と模型の海浜断面形状および砕波点の位 置の相違が，それぞれ式（2），（3）および（4）で表 わされる実験誤差の 2 倍以内に納まる場合を相似とす る. 一方, 海浜断面形状が正常海浜亡暴風海浜のように 根本的に異なるかあるいは実験誤差の 4 倍以上の相違が ある場合を非相似とし，両者の中間的なものを擬相似と する.

\section{3. 海浜変形の相似則に関する実験}

実験的に海浜変形の相似則を求めるために，次の思想 に基づいて実験を行う．すなわち，原型と模型の外力で ある波特性の縮尺(実験縮尺) は Froude の相似則に従っ て定める。一方，底質特性（粒径縮尺）はFroude 則と
は無関係に定める．換言するならば，実験縮尺に対して 粒径縮尺をひずませて，海浜変形が相似（漂砂が相似） となる場合の関係を見出す.

したがって，原型はできる限り現地海岸に近いスケー ルの実験が可能な京都大学防災研究所付属宇治川水理実 験所の長さ約 $78 \mathrm{~m}$, 幅 $1 \mathrm{~m}$, および深さ $1.5 \mathrm{~m}$ のコン クリート造のフラッター式造波機を取り付けた波浪水槽 を使用した。この波浪水槽で，波を 60 時間作用させ， ほとんど平衡状態になった海浜断面形状と実験条件 (Table 1 中の No.1) を原型とした。ささらに, Saville ${ }^{5}$ は，ピストン型の造波機を有する長さ $194 \mathrm{~m}$, 幅 $4.6 \mathrm{~m}$, および深さ $6 \mathrm{~m}$ の超大型造波水槽に砂で $1 / 15$ の一様な 初期勾配を造り, California $の$ Mission Beach と同程 度の波を作用させた実験結果（Table 1 中の No. 8) を 報告しているので，この実験も原型とする.

一方, 模型としては, 名城大学理工学部土木工学科の 長さ $28 \mathrm{~m}$, 幅 $1 \mathrm{~m}$ ，および深さ $1 \mathrm{~m}$ の鋼鉄製片面ガラ ス張りで, フラッター式の造波機を有する造波水槽内を 幅 $50 \mathrm{~cm}$ に中仕切板で 2 分し, その片側を使用した. 模型の実験条件は前述の研究思想に基づいて, 海浜断面 形状の鉛直および水平方向の長さの寸法は, 幾何学的相 似則に従うものとし，縮尺のひずみは与えず，原型と模 型の初期浜勾配を同一にする. 外力としての波高および 周期などの波の特性については，Froude の相似則に 従って定め, 海浜の変形が平衡状態になったと考えられ るまで波を作用させる，また，模型の底質には，原型と 同程度の比重を有する砂あるいは珪砂を使用し，粒径は Froude 則とは無関係に定めることにする。

このような実験方法の一例として, Table 1 に示した ように，原型と模型の底質の粒径縮尺を一定とし，波の 縮尺を徐々に変化させて実験した。なお，原型と模型で 使用する造波水槽の規模，造波機の形式，および初期汀 線から造波板までの距離が幾何学的に相似になるよう配 慮したが, 模型の縮尺によっては，これらの相似性が十 分満足されない場合も生じた。実験中，沖波波高 $H_{0}$ お よび水の動粘性係数 $\nu$ が若干変動するので, 実験中の

Table 1 An example of experimental conditions for prototypes and models.

\begin{tabular}{|c|c|c|c|c|c|c|c|c|c|c|c|c|c|}
\hline No. & Scale & Run No. & $i_{0}$ & $\begin{array}{c}d 50 \\
(\mathrm{~mm})\end{array}$ & $\begin{array}{c}T \\
(\mathrm{~s})\end{array}$ & $\begin{array}{c}H_{0} \\
(\mathrm{~cm})\end{array}$ & $\begin{array}{c}h \\
(\mathrm{~cm})\end{array}$ & $H_{0} / L_{0}$ & $\begin{array}{l}d 50 / H_{0} \\
\left(\times 10^{-3}\right)\end{array}$ & $h / L_{0}$ & $\frac{\sqrt{g H_{0}} \cdot d_{50}}{\nu}$ & $\begin{array}{c}t / T \\
\left(\times 10^{4}\right)\end{array}$ & Remarks \\
\hline 1 & Proto. & 4 & \multirow{7}{*}{$1 / 30$} & 0.94 & 2.00 & 21.8 & 100.0 & 0.035 & 4.3 & \multirow{7}{*}{0.16} & 1060 & 10.8 & \multirow{7}{*}{$\begin{array}{l}\text { Equilibrium } \\
\text { beach } \\
\text { profile }\end{array}$} \\
\hline 2 & $1 / 1.82$ & $4 \mathrm{M}-20$ & & 0.42 & 1.48 & 14.2 & 55.0 & 0.042 & 3.0 & & 433 & 5.8 & \\
\hline 3 & $1 / 2$ & $4 \mathrm{M}-19$ & & 0.42 & 1.41 & 12.1 & 50.0 & 0.039 & 3.5 & & 401 & 6.1 & \\
\hline 4 & $1 / 3$ & $4 \mathrm{M}-18$ & & 0.42 & 1.15 & 8.1 & 33.3 & 0.039 & 5.2 & & 328 & 7.5 & \\
\hline 5 & $1 / 4$ & $4 \mathrm{M}-17$ & & 0.42 & 1.00 & 5.8 & 25.0 & 0.037 & 7.2 & & 278 & 8.6 & \\
\hline 6 & $1 / 5$ & $4 M-16$ & & 0.42 & 0.89 & 4.8 & 20.0 & 0.039 & 8.8 & & 253 & 9.7 & \\
\hline 7 & $1 / 6.7$ & $4 M-15$ & & 0.42 & 0.77 & 3.6 & 15.0 & 0.039 & 11.7 & & 219 & 11.2 & \\
\hline 8 & Proto. & T -52 & \multirow{4}{*}{$1 / 15$} & 0.22 & 5.6 & 171.2 & 442.0 & 0.035 & 0.13 & 9.0 & 790 & 2.6 & \multirow{4}{*}{$\begin{array}{c}=\text { Saville } \\
(1957) \\
\nu: 15^{\circ} \mathrm{C}\end{array}$} \\
\hline 9 & $1 / 8$ & $\mathrm{~T}-57$ & & 0.15 & 1.98 & 20.4 & 55.3 & 0.033 & 0.74 & 9.0 & 219 & 2.6 & \\
\hline 10 & $1 / 20$ & $\mathrm{~T}-58$ & & 0.15 & 1.25 & 7.7 & 22.1 & 0.032 & 1.95 & 9.0 & 132 & 2.5 & \\
\hline 11 & $1 / 30$ & $\mathrm{~T}-59$ & & 0.15 & 1.02 & 5.8 & 14.7 & 0.036 & 2.59 & 9.0 & 119 & 2.6 & \\
\hline
\end{tabular}


値を平均して, Table 1 に示してある.

\section{（1）実験結果とその相似性}

Table 1 の No.1 (Run No.4) を原型として, No.2 〜 ( Run No. 4 M-20〜4 M-15) を模型とした場合, 両者の海浜断面形状の比較の一例を Fig. 3 (a) に示す. この図中には，砕波点の位置，相対砕波高 $\left(H_{b} / H_{0}\right)$ お よび砕波形式が併示してある、また，Table 1 の No. 8 (Run No. T-52) で示す Saville の実験結果を原型とし， それに対する模型，No.9－11（Run No. T-57〜T-59) との比較を Fig. 3 (b) に示す. すべての実験結果をこ のように整理した後，前述した判定基準で原型と模型の 相似性を定量的に比較照合し, 相似 (○印), 擬相似 $(\triangle$ 印）および非相似（の印）のいずれかに分類する.

Fig. 3 の左側に，このような判定結果が示してある.

このような方法ですべての実験結果を比較判定し，模 型の底質の中央粒径 $(d)_{m}$ と原型 $(d)_{p}$ との比の逆数 : $1 /\left|(d)_{m} /(d)_{p}\right|=1 / \lambda_{d}$ を縦軸に，模型と原型の沖波波高比 の逆数：1/\{(Ho $\left.H_{m} /\left(H_{0}\right)_{p}\right\}=1 / \lambda_{H_{0}}=n$ を横軸に取って整理 し，その中で，原型の粒径・波高比が $(d)_{p} /\left(H_{0}\right)_{\rho} \leq 0.01$ の条件を満たすものを Fig. 4 に示す.しかしながら， $(d)_{p} /\left(H_{0}\right)_{p}>0.01$ の場合には, 十分な実験数が得られな

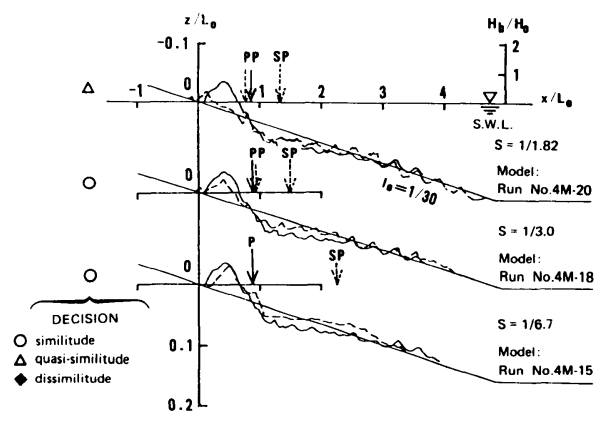

(a) Prototype: Run No. 4



(b) Prototype: Run No. T-52

Fig. 3 Similarity between prototype beach profiles (solid curves) and models (broken curves). ( $\mathrm{P}$ : plunging, $\mathrm{S}$ : surging, and $\mathrm{SP}$ : spilling breaker).
かったので，本研究の対象から外してある，また，他の 研究者の実験の中で, 本研究の主旨と類似しており, 前 述の条件および初期浜勾配 $i_{0}=1 / 10 \sim 1 / 30$, 沖波波形 勾配 $H_{0} / L_{0}=0.031 \sim 0.042$ の範囲で行った Saville,

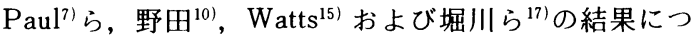
いても相似性を判定し, Fig. 4 に併示した. Fig. 4 で, Watts および堀川らの実験結果は，原型と模型の実験縮 尺が同じで，粒径縮尺のみが変化する場合である。

このように，かなり多くの実験結果を整理した Fig. 4 の中を，相似，擬相似および非相似の 3 領域に区分する ことができる.

\section{（2）海浜断面形状の定性的（タイプ）相似性}

これまでに，現地海岸の再現実験がいくつか行われ， それらの実験結果のいくつかは現地海浜の変形を定性的 に再現できたと報告している．そこで，従来の再現実験 結果と本研究との比較をするために，定性的な判定基準 を用いた場合の相似則を検討する.

定性的な判定基準として, 堀川・砂村ら ${ }^{17)}$ の海浜断面 形状をタイプ別に分類する方法を参考にし，原型および 模型の平衡海浜断面形状および初期地形からの変動につ いて，次のように分類する.

タイプI：汀線が後退し, 沖に砂が堆積するbar 型地 形.

タイプII：汀線の前進・進退量が非常に少なく実験誤 差以内で, いわゆるタイプI およびタイプ IIIのいずれにも属さない地形.

タイプIII：汀線が前進し，沖に砂が堆積しない step

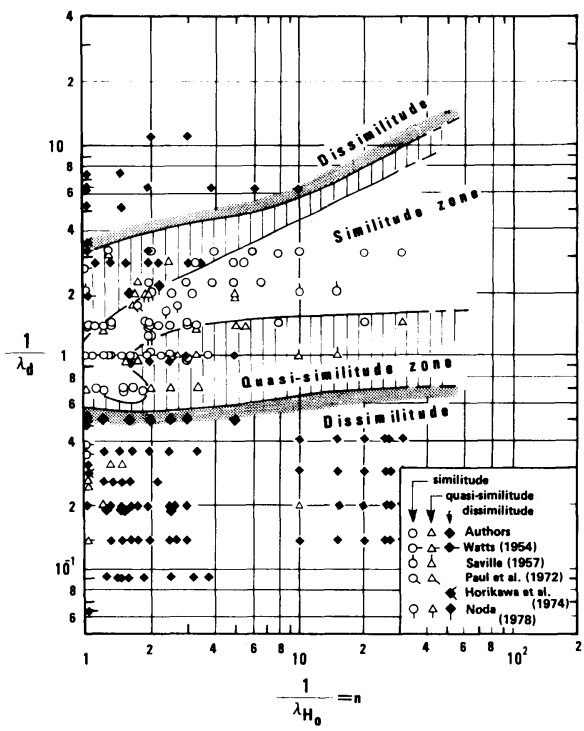

Fig. 4 Graphical representation of similitude of beach profiles. $\left[\begin{array}{l}\text { Ranges of experimental conditions of prototype ; } \\ H_{0} / L_{0}=0.031 \sim 0.042, d / H_{0} \leq 0.01, \text { and } i_{0}=1 / 10 \sim 1 / 30 .\end{array}\right]$ 
型地形.

原型と模型の海浜断面形状をこれらの 3 種類のタイプ に分け，両者のタイプが同じとなる場合を相似 (O印), タイプI と而のように全く相反する場合を非相似(け印) およびタイプ I と II あるいは II とIII となる場合を擬相似 ( $\triangle$ 印) として分類する．ささら，現地海岸を対象にし



Fig. 5 Similitude of beach type.

$\left[\begin{array}{l}\text { Ranges of experimental conditions of prototype ; } \\ H_{0} / L_{0}=0.31 \sim 0.42, d / H_{0} \leq 0.01, \text { and } i_{0}=1 / 10 \sim 1 / 30\end{array}\right]$

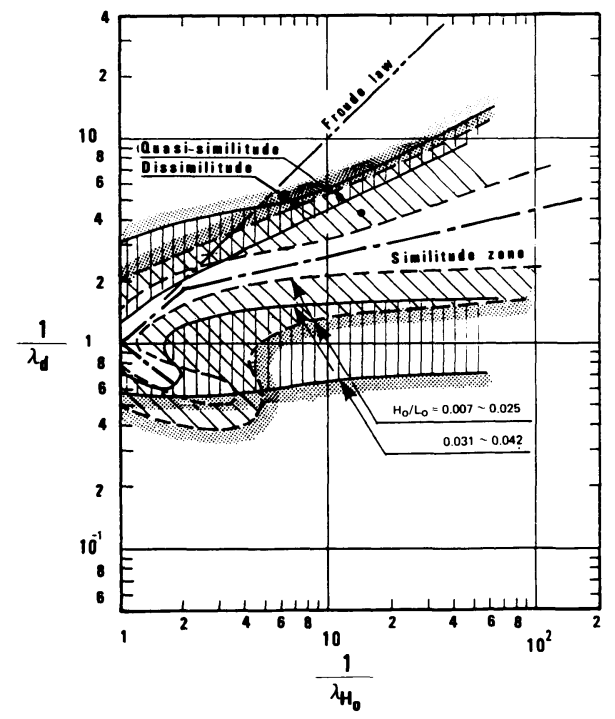

Fig. 6 Similitude of beach profile within range of $H_{0} / L_{0}=0.007 \sim 0.042$.

$\left[\begin{array}{l}\text { Ranges of experimental conditions of prototype ; } \\ d / H_{0} \leq 0.01 \text { and } i_{0}=1 / 10 \sim 1 / 30\end{array}\right]$
た従来の三次元模型実験の中で, 定性的に相似性の判定

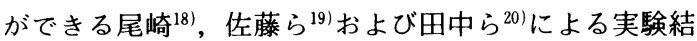
果 $\left(H_{0} / L_{0}=0.031 \sim 0.042\right)$ についても同様に分類・判 定した.これらの結果を Fig. 5 のように整理すると, 図 中を相似，擬相似および非相似の各領域に分けることが できる.この図で示される相似および擬相似の領域は Fig. 4 の傾向とよく一致することがわかる.

\section{（3）海浜变形の相似則}

相似則が定量的に成立する領域を示す Fig. 4 と, 著者 らが，従来沖波波形勾配の比較的小さい場合 $\left(H_{0} / L_{0}=\right.$ 0.007〜0.025）について整理した結果 ${ }^{21), 22)}$ とを重ね合わ せると，Fig. 6 のように表わせる．この図から，相似則 の成立領域は沖波波形勾配の相違による若干の違いがみ られるが，傾向はよく類似している．また，共通して相 似則が成立する領域は，ある幅の間に存在している。こ のように相似則の成立する領域がある幅で存在する原因 の 1 つとして, 前述の実験誤差による影響が考えられる. Fig. 6 に示した相似則の成立する領域は, $1 / \lambda_{d} \geq 1$ と $1 / \lambda_{d}<1$ の 2 つ部分にまたがっている. すなわち, $1 / \lambda_{d}>1$ の部分では, 相似則の成立する領域は, 実験縮 尺 $1 / \lambda_{H_{0}}=1 \sim 2.2$ の範囲で Froude の相似則 $\left(1 / \lambda_{d}=\right.$ $\left.1 / \lambda_{H_{0}}\right)$ とよく一致する. さらに，縮尺が $1 / \lambda_{H_{0}}=2.2 \sim$ 100 の範囲になると, Froude の相似則からはずれる. このことは，波に関する実験縮尺を Froude の相似則で 定めると, 模型の底質粒径は, Froude の相似則で規定 される値より粗く,かつ原型より若干細かい値にすれば, 相似則が成立することを示唆している.

一方, $1 / \lambda_{d}<1$ の部分では, 相似則が成立する領域は, 縮尺 $1 / \lambda_{H_{0}}=1 \sim 2.2$ の範囲に限って，波之底質に関する Reynolds 数 $\left(\sqrt{g H_{0}} d / \nu\right)$ による相似則 $1 / \lambda_{d}=(1 /$ $\left.\lambda_{H_{0}}\right)^{-1 / 2}$ とよく一致する.

このように相似則が成立する領域の中央部分を一点鎖 線で Fig. 6 中に示してある.この線は次式で表わすこと ができる。

$$
\frac{1}{\lambda_{d}}=1.7^{a}\left(\frac{1}{\lambda_{H_{0}}}\right)^{b}
$$

あるいは,

$$
\frac{(d)_{m}}{(d)_{p}}=\left(\frac{1}{1.7}\right)^{a}\left(\frac{1}{n}\right)^{b}
$$

\begin{tabular}{|c|c|c|c|}
\hline \multicolumn{2}{|c|}{$\underbrace{\text { Expermental }}_{\text {Exponent }}$} & $1>\frac{1}{n} \geq \frac{1}{2.2}$ & $\frac{1}{2.2}>\frac{1}{n}$ \\
\hline$\lambda_{11}<1$ & $\begin{array}{l}a \\
b \\
\end{array}$ & $\begin{array}{l}0 \\
0.87 \\
\end{array}$ & $\begin{array}{l}1 \\
0.2 \\
\end{array}$ \\
\hline$\lambda_{11}>1$ & $\begin{array}{l}a \\
b\end{array}$ & $\begin{array}{c}0 \\
-0.8 \\
\end{array}$ & \\
\hline
\end{tabular}


ここに，ベキ指数 $a$ および $b$ の值はそれぞれ Table 2 で表わされる. $(d)_{m}$ および $(d)_{p}$ はそれぞれ模型および 原型の底質粒径，および $1 / n$ は実験縮尺である. 特に, $\lambda_{d}<1$ のときの式（5）あるいは（6）は，実用的であ るのでこれを海浜変形の相似則としよう.そうすれば, 漂砂の粒径縮尺を式（6）の相似則, 波の特性および長 さに関する縮尺を Froude の相似則で，それぞれ定める ことによって, 原型と模型の相似性を確保することがで きる.

\section{4. 海浜変形の特性に関する表示式および図に よる相似則}

\section{（1）表示式および図}

海浜変形の相似則は, 支配している真の力学的法則が わかっておれば，それから求めるべきものであろう．現 在, 残念ながら，この法則はまだ明らかになっていない。 そこで, 汀線の移動, 漂砂の移動限界水深, および海浜 断面形状なざの個々の特性を詳しく調べた従来の研究成 果から相似則を導く.これらの相似則と前述した式 (6) の相似則との関係については，次章で考察する.

海浜変形の特性に関する従来の主要な研究が Table 3 中の第(4)列に系統的に分類整理してある.また，第(5)列， (6)列にはそれぞれの相似則を示す．表中， $d$; 底質粒径, $d_{m}(\approx d)$; 平均粒径, $d_{50}(\approx d)$; 中央粒径, $\omega$; 底質の沈 降速度, $s(=\sigma / \rho-1)$; 底質の水中比重, $\sigma / \rho$; 底質の比 重, $\nu$; 動粘性係数, $h$; 水平床部の水深, $H$; 波高, $H_{0}$; 沖波波高, $H_{b}$; 砕波高, $L$; 波長, $L_{0}$; 沖波波長, $T$; 周期, $t$; 波の作用時間, $i_{0}=\tan \beta$; 初期浜勾配, $X_{s l}$; 汀線移動量, $l ;$; 海浜の長さのスケール, $h_{i}$; 漂砂の移動 限界水深, $\bar{h}_{i}$; 海浜の変形限界水深, $\lambda_{x}$; 水平方向の縮尺, $\lambda_{y}$; 鉛直方向の縮尺, $C_{1}, C_{2}, \alpha, n^{\prime}, A^{\prime}, B^{\prime}$; 定数, $\delta$; 層 流境界層厚, $u_{c}^{*}$; 限界摩擦速度, $\varepsilon$; 底質の空隙率, お よび $g ;$ 重力の加速度である.

\section{（2）相似則の誘道と表示}

原型 (prototype) と模型 (model) との比を次の表 示法で, Table 3 中の第(4)列から相似則を求めた結果が 第(5)列にまとめてある.

$$
\lambda_{\text {parameter }}=\frac{\text { 模型の寸法 (parameter) }}{\text { 型の寸法 (parameter) }}
$$

さらに, 原型と模型で, 水平・鉛直方向が同縮尺（ $\lambda_{x}=$ $\left.\lambda_{y}=\lambda_{H_{0}}=\lambda_{L_{0}}, \lambda_{t_{0}}=\lambda_{\tan \beta}=1\right)$, 底質には同程度の比重の 砂を使用 $\left(\lambda_{s}=1\right)$, 同程度の温水の水 $\left(\lambda_{\nu}=1\right)$, 平衡海 浜断面形状を対象 $\left(\lambda_{t}=1\right)$, および重力の加速度が同じ $\left(\lambda_{g}=1\right)$ として, 本研究の実験と同じ条件にして整理 した相似則が第(6)列に示してある．第(6)列の各種相似則 が, Fig. 6 と同様に, 砂の粒径縮尺 $1 / \lambda_{d}$ を繸軸, 実験 縮尺 $1 / \lambda_{H_{0}}$ を横軸に取って，後述の $\left.\left.\mathbf{a}\right) \sim \mathrm{c}\right)$ の諸点を考
慮して, Fig.8 (a) 〜 (e) に示してある. 図中の記号 A $\sim \mathrm{N}$ は, Table 3 の第(2)列の No. に対応させてある. 特 に, Fig. 8 (a) 中の No.A で示される直線関係は, 粒 径縮尺と実験縮尺が同じになる場合である。しかし，両 者の縮尺間にひずみがある場合には，No.A の直線とは 一致しなくなる。

\section{a ) 汀線の移動}

Table 3 中, No. B の第(4)列に示した式は, 波のスケ一 ルが小さい実験結果と, スケールの大きい現地のものと では, 式中の定数が異なる (実験 : $C_{1}=10$, 現地： $C_{1}$ =18)ので, この点に留意して Fig. 8 (a) に示してある.

また，Table 3 中 No. D の汀線の移動量を表示する 10 変量多項式 (無次元量 $h / L_{0}, d / H_{0}, i_{0}, H_{0} / L_{0}$, およ び $\sqrt{g H_{0}} \cdot d / \nu$ で構成されている) が，原型と模型のあ らゆる条件下で常に成立するためには，原型のみの場合 である。しかし，限られた条件（たとえば， $(d)_{p} /\left(H_{0}\right)_{p}$ $\leq 0.01, H_{0} / L_{0}=0.035$ で, $i_{0}=1 / 15$ あるいは $1 / 30$, 汀 線移動量 $X_{s l} / L_{0}= \pm 0.1$ あるいは一 0.3 など）では，相 似則の成立する関係が $(d)_{p} /\left(H_{0}\right)_{p}$ の比によって決まるの で，その一例を Fig. 8 (b) に示す.

b ） 漂砂の移動限界水深

Table 3 中の Nos. E, F およびGで示される漂砂の移 動限界水深の表示式は, 水平移動床の実験によるもので, No. E は実験之現地海岸で式中の定数 $\alpha$ を変えなければ ならない。これらの表示式を傾斜海浜に適用する場合に ついて考案する.

著者らおよびその他の研究者による実験の中で，海浜 変形が一様な初期勾配内で起こり, 沖浜領域で初期浜勾

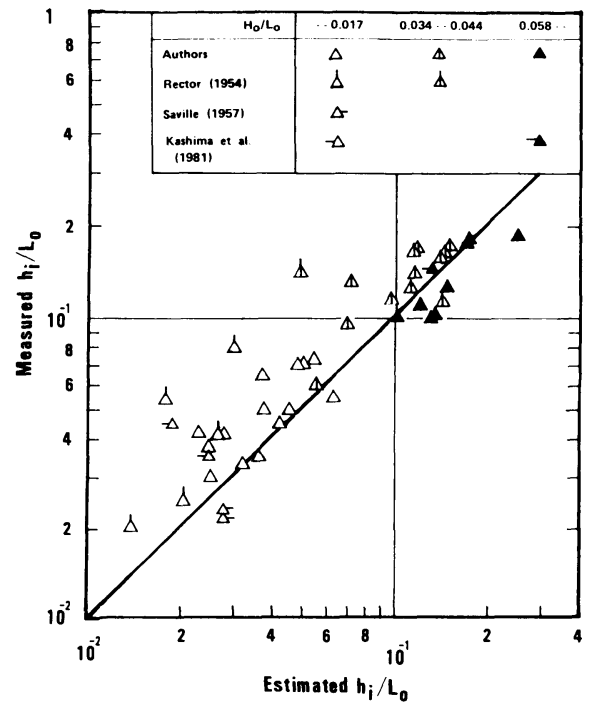

Fig. 7 Comparison of critical water depth for beach change $\bar{h}_{i} / L_{0}$ and sediment movement $h_{i} / L_{0}$. 
Table 3 List of similitudes derived from characteristics of beach change.

\begin{tabular}{|c|c|c|c|c|c|c|}
\hline $\begin{array}{l}\text { 区 } \\
\text { 分 }\end{array}$ & (2) & $\begin{array}{l}\text { (3) } \\
\text { 硎 究 者 } \\
\text { (発表年) }\end{array}$ & $\begin{array}{l}\text { (4) } \\
\text { 海浜断泊形状特性の表小式 } \\
\text { あるいは関係図 }\end{array}$ & $\begin{array}{c}\text { (5) } \\
\text { (4) による相似則 }\end{array}$ & $\begin{array}{l}6 \\
\lambda_{x}=\lambda_{y}=\lambda_{H_{0}}=\lambda_{L_{0}} \\
\lambda_{s}=1, \lambda_{i_{0}}=\lambda_{\tan \beta}=1, \\
\lambda_{T}=\lambda_{x}^{1}, \lambda_{L}=1 f j よ U ゙ \\
\lambda_{g}=1 \text { の場合 }\end{array}$ & $\begin{array}{l}\text { (7) } \\
\text { 備 考 }\end{array}$ \\
\hline & A & $\begin{array}{l}\text { 坡川・仯村· } \\
\text { 近滕17) } \\
(1974)\end{array}$ & 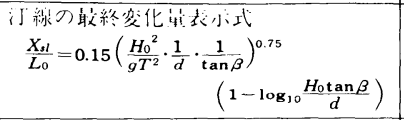 & $\begin{array}{l}\lambda_{i 1}^{1} \lambda^{2}{ }_{H_{0}}^{2} \lambda_{L_{0}}^{1} \lambda_{\tan \beta}=1 \\
\lambda_{11}{ }^{1} \lambda_{H_{0}} \lambda_{\tan \beta}=1\end{array}$ & $\lambda_{d}=\lambda_{H_{0}}$ & \\
\hline $\begin{array}{c}\text { i丁 } \\
\text { 線 }\end{array}$ & B & 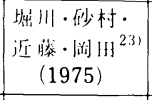 & 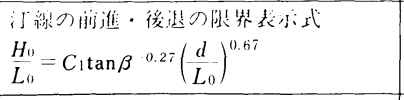 & $\left(\frac{10}{18}\right) \lambda_{d}^{0.67} \lambda_{H_{0}}^{-1} \lambda_{L_{0}}^{0.33} \lambda_{\tan \beta}^{-0.27}=1$ & $\lambda_{11}=\frac{1}{0.42} \lambda H_{0}$ & 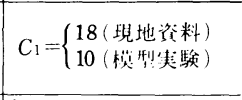 \\
\hline $\begin{array}{l}\text { の } \\
\text { 移 } \\
\text { 動 }\end{array}$ & C & 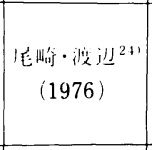 & $\frac{H_{0}}{L_{0}} \sqrt{g H_{b}} d_{50}^{-1.8} \tan \beta \underset{<}{>} 164$ 汀線後絷進 & 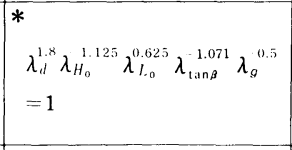 & $\lambda_{1}=\lambda_{H_{0}}^{1,3.6}$ & $\begin{array}{l}\text { * Le Méhauté-Koh } \\
\quad(1966) の 土 \\
: \frac{H_{0}}{H_{b}}=0.76 \tan \beta^{1 / 7}\left(\frac{H_{0}}{L_{0}}\right)^{-1 / 4} \\
\text { 虑明いて変形 }\end{array}$ \\
\hline & $\mathrm{D}$ & $\mid \begin{array}{c}\text { 仯滕·增 }\left(1 \mathrm{H}^{25}{ }^{25}\right. \\
(1982)\end{array}$ & 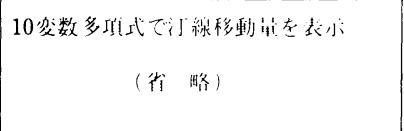 & 55佃の)机似断 & $\begin{array}{c}\lambda_{11}=\lambda_{x}^{a} \\
\left(\begin{array}{c}a=\bar{a} / 2,1,1 / 2,1 / 1, \\
-1 / 2,-2\end{array}\right) \\
\lambda H_{0}=\lambda_{x}^{b},(b=0,1)\end{array}$ & \\
\hline \multirow{3}{*}{ 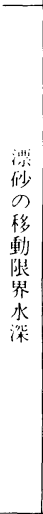 } & $\mathrm{E}$ & $\mid \begin{array}{c}\mid \text { 值藤・男中中 26) } \\
(1962)\end{array}$ & $\frac{H_{0}}{L_{0}}=\alpha\left(\frac{d}{L_{0}}\right)^{n}\left(\sinh \frac{2 \pi h_{i}}{L_{0}}\right) \frac{H_{0}}{H}$ & $\lambda_{a} \lambda^{n} \lambda^{n} \lambda_{H}{ }^{1} \lambda_{I_{H_{0}}}^{1}{ }^{n}=1$ & $\left(\frac{1}{0.073} \sim \frac{1}{0.013}\right) \lambda_{H_{0}}$ & 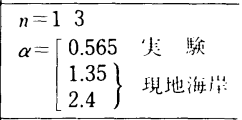 \\
\hline & $\mathrm{F}$ & $\begin{array}{c}\text { 坮川・渡训 } 271 \\
(1966)\end{array}$ & 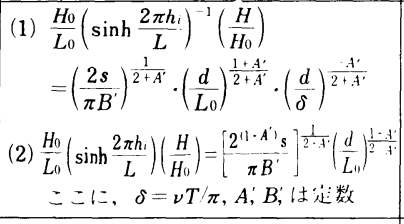 & 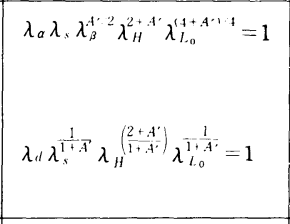 & 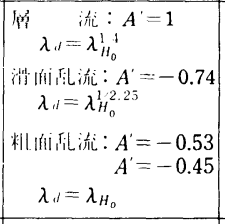 & 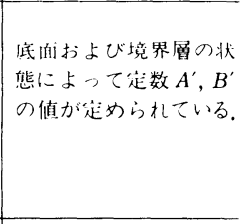 \\
\hline & $G$ & $\begin{array}{l}\text { 椹 } \text { 小 }^{281} \\
(1961)\end{array}$ & $\begin{array}{l}\text { (1) } u_{c^{*}} d / \nu<10 \\
u_{c^{*}} 2 /\left\{\left(\frac{\sigma}{\rho}-1\right) g d\right\}=0.114\left(u_{*}^{*} d / \nu\right)^{2 / 3} \\
\text { (2) } 10<u_{c^{*}} d / \nu<60 ; \\
u_{c^{*}} /\left\{\left(\begin{array}{c}\sigma \\
\rho\end{array}-1\right) g d\right\}=0.028\end{array}$ & $\begin{array}{l}\lambda_{11}=\lambda_{s}{ }^{3} \lambda_{y} \\
\lambda_{11}=\lambda_{s}{ }^{1} \lambda_{y}^{1-4}\end{array}$ & $\begin{array}{l}\lambda_{11}=\lambda_{x} \\
\lambda_{11}=\lambda_{x}^{1+}\end{array}$ & \\
\hline \multirow{2}{*}{\multicolumn{2}{|c|}{ 海 }} & $\begin{array}{c}\text { J.W. Johnson } \\
\text { (1949) }\end{array}$ & 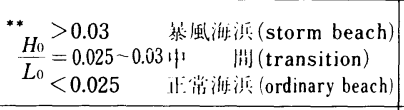 & $\lambda_{H_{0}} \lambda_{I_{0}}^{\prime}=1$ & 漟に成桴 & 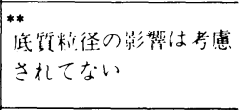 \\
\hline & & $\mid \begin{array}{c}\text { 岩暏 } \cdot \text { 野(日十 }{ }^{6)} \\
(1961)\end{array}$ & $\begin{array}{l}\frac{l}{L_{0}}= \\
\quad f\left\{\frac{H_{0}}{L_{0}}, \frac{d_{m}}{H_{0}}, \frac{t}{T},\left(\frac{\sigma}{\rho}-1\right), \frac{v}{d_{m} \sqrt{g H_{0}}}, i_{0}\right\}\end{array}$ & $\begin{array}{l}\lambda_{H_{0}} \lambda_{I_{0}}^{1}=1, \lambda_{*}=1 \\
\lambda_{11} \lambda_{H_{0}^{1}}=1, \lambda_{1}{ }^{1} \lambda_{H_{0}}{ }^{2}{ }^{2} \lambda_{2} \lambda_{g}{ }^{2}{ }^{2}=1 \\
\lambda_{1} \lambda_{r}{ }^{1}=1, \quad \lambda_{I_{0}}=1\end{array}$ & $\begin{array}{l}\lambda_{d}=\lambda H_{0} \\
\lambda_{d}=\lambda_{H_{0}}^{-12}\end{array}$ & \\
\hline 浜 & $\mathrm{J}$ & $\begin{array}{c}\text { E.K. Noda } \\
(1972)\end{array}$ & & $\begin{array}{l}\lambda_{1} \lambda_{*}^{1.85}=\lambda_{y}^{0.55} \\
\lambda_{x}=\lambda_{4}^{1.32} \lambda_{*}^{(0.3865}\end{array}$ & 综些のみ成泣 & $\begin{array}{l}\text { 汀線付近の海浜断面形 } \\
\text { 状を对象にした相似則 } \\
\end{array}$ \\
\hline \multirow{4}{*}{$\begin{array}{l}\text { 的 } \\
\text { 形 } \\
\text { 状 }\end{array}$} & $\mathrm{K}$ & $\begin{array}{c}\begin{array}{c}\text { R. G. Dean } \\
\text { (19) } \\
(1973)\end{array} \\
\end{array}$ & $\begin{array}{ll}\frac{H_{0}}{L_{0}}<1.7 \frac{\pi \omega}{g T} & \begin{array}{l}\text { 暴風海浜 } \\
\text { 常海浜 }\end{array} \\
\end{array}$ & $\lambda_{\omega} \lambda_{H_{0}}^{1} \lambda_{l_{0}}^{1}{ }^{2} \lambda_{g}{ }^{12}=1$ & $\lambda_{\dot{\omega}}=\lambda_{H_{0}}^{1}{ }^{2}$ & \\
\hline & $\mathrm{L}$ & $\begin{array}{l}\text { 堀川·砂村· } \\
\text { 近滕17) } \\
(1974)\end{array}$ & $\begin{array}{l}\frac{H_{0}}{L_{0}}=C_{2} \tan \beta^{-0.27}\left(\frac{d}{L_{0}}\right)^{0.67} \\
C_{2} \text { の做による海浜断响のタイフ分け }\end{array}$ & $\frac{4}{9} \lambda_{i l}^{0.67} \lambda H_{0}^{1} \lambda_{L_{0}}^{0.33} \lambda_{\operatorname{lan} \beta}^{0.27}=1$ & $\lambda_{1}=\frac{1}{0.24} \lambda H_{0}$ & $\begin{array}{ll}C_{2} \geqq 7 & : \text { タイプI } \\
4 \leqq C_{2} \leqq 7 & : \text { タイプII } \\
C_{2} \leqq 4 & : \text { タイプIII }\end{array}$ \\
\hline & $\mathrm{M}$ & $\begin{array}{l}\text { R. A. } \\
\text { Dalrymphe } \\
\text { et al.9! } \\
\quad(1976) \\
\end{array}$ & $\begin{array}{l}\frac{H_{0}}{L_{0}}, \text { Froude の机似則，および沈济 } \\
\text { 速没表小式から机似則を求わた。 }\end{array}$ & $\begin{array}{l}\lambda_{x}=\lambda_{y} \\
\lambda_{T}=\lambda_{y}^{12} \\
\lambda_{\omega}=\lambda_{y}^{1} 2\end{array}$ & $\lambda_{\omega}=\lambda_{y}^{1 / 2}$ & 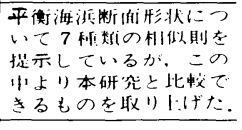 \\
\hline & $\mathrm{N}$ & $\begin{array}{c}\text { 服部・川又独 } \\
(1978)\end{array}$ & 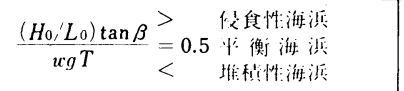 & $\lambda_{\omega} \lambda_{H_{0}}{ }^{1} \lambda_{L_{0}}^{1 / 2} \lambda_{1, n \beta}{ }^{1} \lambda_{g}^{-1 / 2}=1$ & $\lambda_{\omega}=\lambda_{H_{0}}^{1 / 2}$ & $\begin{array}{l}\text { 砕波带の二次元海浜変 } \\
\text { 形を対象にした分類法 }\end{array}$ \\
\hline
\end{tabular}

配からの変形が顕著になる点を読み取り，これに対応し た水深を海浜変形の限界水深 $\bar{h}_{i}$ として, $\bar{h}_{l} / L_{0}$ で無次 元表示する.このときの実験条件を用いて, 佐藤・田中 ${ }^{191}$ および堀川・渡辺 ${ }^{27)}$ の式から漂砂の移動限界水深 $h_{i} / L_{0}$
を計算した.佐藤・田中の完全移動限界水深の表示式で, 著者らおよび Rector ${ }^{32}$ の比較的スケールの小さい実験 資料 $\left(H_{0}=3.5 \sim 29 \mathrm{~cm}\right)$ については， $\alpha=0.565$ (実験)

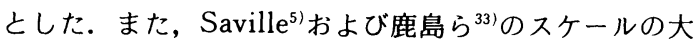


きな実験資料（ $H_{0}=46 \sim 107 \mathrm{~cm} ）$ については，鹿島港 沿岸の現地観測による $\alpha=1.35$ とした。こうして求め られた漂砂の無次元移動限界水深 $h_{i} / L_{0}$ と海浜変形の 限界水深 $\bar{h}_{i} / L_{0}$ とが比較的よく対応する佐藤・田中の 式による結果が Fig.7に示してある.この図から, 図示 した值は多少ばらつき, 海浜変形の限界水深の方が若干 深いが， $\bar{h}_{i} / L_{0}$ と $h_{i} / L_{0}$ との間に対応関係があること がわかる. 以上の簡単な比較から, Table 3 中の No. E の第(4)列の式は, 波のスケールによって定数 $\alpha$ の值を 使い分けねばならないことがわかる. そこで, 実験 $(\alpha$ $=0.565)$ と鹿島港沿岸 $(\alpha=1.35)$ および仙台湾沿岸 ${ }^{34)}(\alpha$ $=2.4)$ を使って求まる関係と, No. F の関係をまとめて, Fig. 8 (c) に示す.

また，椹木 ${ }^{28)}$ は，非定常流の実験結果を用いて，層流 境界層における砂の移動限界表示式を限界掃流力 $u_{c}^{* 2}$ /

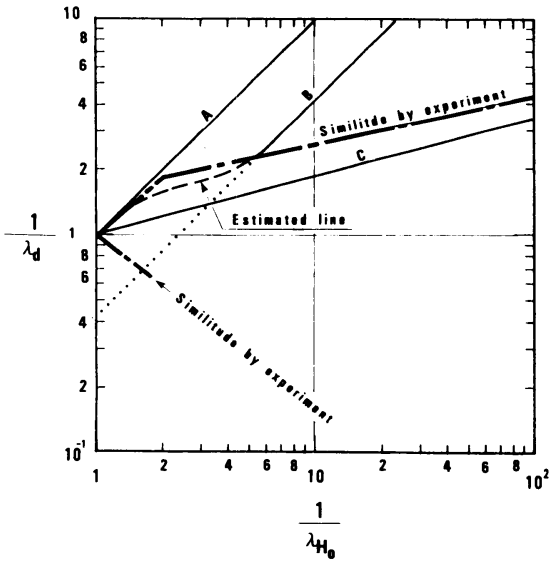

(a) Nos. A, B, and C (shoreline change)

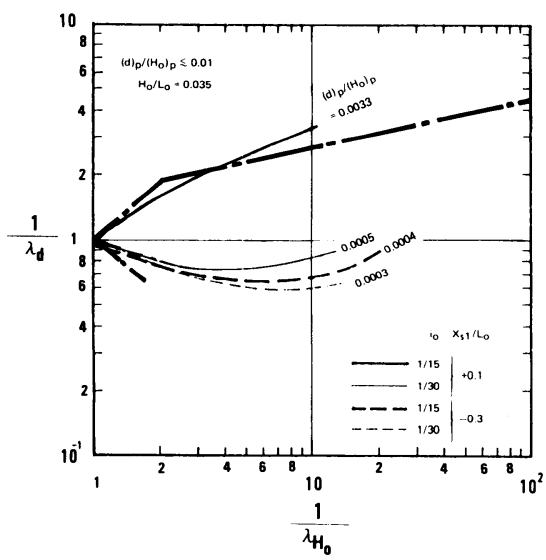

(b) No. D (shoreline change)

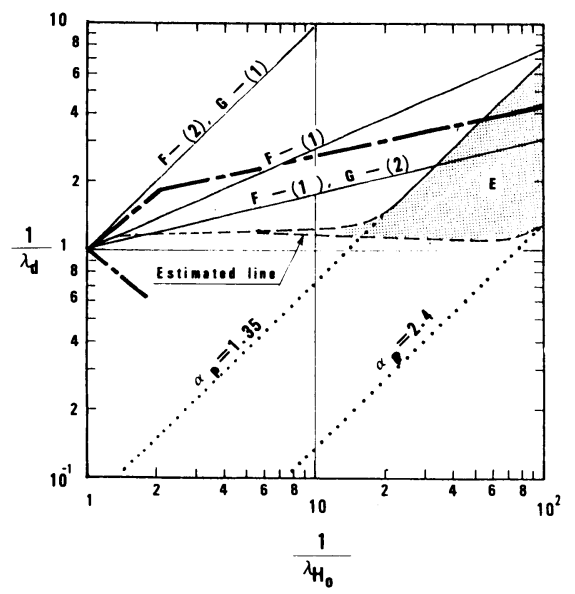

(c) Nos. E, F, and G (critical water depth of sediment movement)

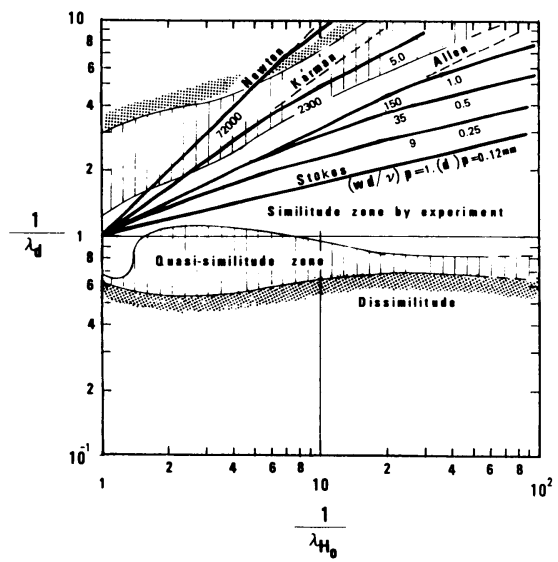

(d) Nos. K, M, and $\mathrm{N}$ (beach profile)

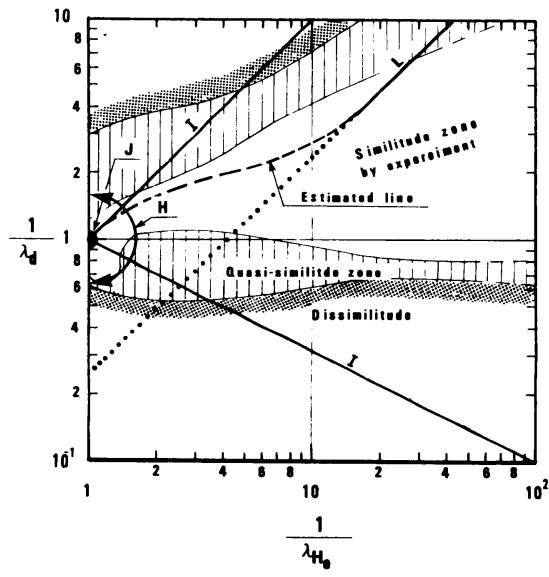

(e) Nos. H, I, J, and L (beach profile)

Fig. 8 Comparisons of similitudes expressed by Eq. (5) or similitude zones illustrated by Fig. 5 and column No. (6) in Table 3.

[Alphabets $\mathrm{A}$ to $\mathrm{N}$ in these figures indicate numbers shown in Table 3.] 
$\left\{\left(\frac{\sigma}{\rho}-1\right) g d\right\}$ と粒子 Reynolds 数 $u_{c}^{*} d / \nu$ の関係で表わ し,この式から次の相似則を導いている.

$$
\left.\begin{array}{c}
\frac{u_{c}^{*} d}{\nu}<10 \text { の場合, } \lambda_{d}=\lambda_{s}^{-3} \lambda_{x} \\
10<\frac{u_{c}^{*} d}{\nu}<60 \text { の場合, } \lambda_{d}=\lambda_{s}^{-1} \lambda_{x}^{1 / 4}
\end{array}\right\}
$$

ここに， $u_{c}^{*}$ は底面の限界摩擦速度である. 式 (8) の相 似則を Fig.8 (c) 中の G-(1) および G-(2) の線で表 わしてある.

\section{c ) 海浜断面形状}

Table 3 中の No. L の第(4)列に示す式は, 実験と現地 海岸で式中の定数 $C_{2}$ が異なる. すなわち，実験結果の 場合，堀川らによる分類では，タイプIこ吕の境界が $C_{2}=4$ であるが, 現地海岸資料では, $C_{2}=9$ である. また， 表中の Nos. K, M およびNの第6)列には，いずれも底 質粒径が沈降速度で表わされているので, 沈降速度と粒 径の相似関係を調べることにする.

沈降速度の表示式 ${ }^{35)}$ には, Stokes, Allen, Kármán, および Newtonの各式があり,これらの式は沈降速度 $\omega$, 流体の動粘性係数 $\nu$ および粒径 $d$ による Reynolds 数 $\left(R_{e}=\omega d / \nu\right)$ によって, その適用範囲が決まっている. これらの式を本研究の実験と同条件 $\left(\lambda_{s}=1, \lambda_{\nu}=1\right.$, お よび $\left.\lambda_{g}=1\right)$ のもとで整理すると, 次式で表わせる.

Stokes の式 $\left(R_{e} \lesssim 4,5\right.$, 砂の水中比重 $s=1.65$, 水の密 度 $\rho=1.0 \mathrm{~g} / \mathrm{cm}^{3}$ のとき, $\left.d \leqq 0.15 \mathrm{~mm}\right)$ ；

$$
\lambda_{\omega}=\lambda_{d}^{2} \lambda_{s} \lambda_{\nu}^{-1} \lambda_{g}=\lambda_{d}^{2}
$$

Allen の式 $\left(R_{e}=4.5 \sim 300, d=0.15 \sim 1.1 \mathrm{~mm}\right)$;

$$
\lambda_{\omega}=\lambda_{d} \lambda_{s}^{2 / 3} \lambda_{\nu}^{-1 / 3} \lambda_{g}^{2 / 3}=\lambda_{d}^{2}
$$

Kármán $の$ 式 $\left(R_{e}=300 \sim 3200, d=1.1 \sim 5.8 \mathrm{~mm}\right)$;

$$
\lambda_{\omega}=\lambda_{d}^{2 / 3} \lambda_{s}^{5 / 9} \lambda_{\nu}^{-1 / 9} \lambda_{g}^{5 / 9}=\lambda_{d}^{2 / 3}
$$

Newton の式 $\left(R_{e}=3200 \sim 10000, d \geq 5.8 \mathrm{~mm}\right)$;

$$
\lambda_{\omega}=\lambda_{d}^{1 / 2} \lambda_{s}^{1 / 2} \lambda_{g}^{1 / 2}=\lambda_{d}^{1 / 2}
$$

これらの関係によれば，Nos. K，M およびNの相似 則は, 原型の $R_{e}$ 数をパラメーターに取って, Fig. 8 (d) のように表わせる. また，これら以外の海浜断面形状に 関する相似則をFig. 8 (e) に示す。

\section{5. 各種相似則の比較検討}

Fig. $8(\mathrm{a}) \sim(\mathrm{e})$ には, 汀線の移動量および漂砂の移 動限界水深などの海浜変形に関する主要な現象の相似則 を Nos. A N で示し，式（6）の相似則を一点鎖線で 示して，比較がしてある.これらの図から，汀線移動に ついては Table 3 中の Nos. C, D, 漂砂の移動限界水深 については Nos. E, F-(1)，および G-(2) の相似則が, 式 ( 6 ) とよく一致する. また, Table 3 の海浜断面形 状の相似則 Nos. H N と Fig. 5 との比較が Fig. 8 (d) および (e) に示してある.これらの比較では, Nos. K,
L， $\mathrm{M}$ およびNの相似則はFig. 5 の傾向とよく一致して いる.このように, 式 (6) および Fig. 5 の相似領域は, 従来の研究結果から求まる相似則ともかなりよく合う.

Fig. 5 で示す海浜変形が定性的に相似となる領域は, 実験縮尺 $\left(1 / \lambda_{H_{0}}=n\right)$ を限定して考えると, Fig. 6 の定 量的なものより粒径縮尺 $\left\{1 / \lambda_{d}=(d)_{D} /(d)_{m}\right\}$ の幅が広く

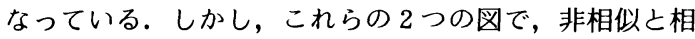
似・擬相似とを分ける境界線がよく一致している.

本研究では, 三次元の海浜変形については, 詳しく検 討しなかったが, Fig. 5 に示した尾崎, 佐藤ら，および 田中らによる現地海岸の平面実験結果は, 式 (6) の傾 向とよく一致している. したがって, 式（6）および Fig. 6 の関係は, 三次元実験にも適用できる可能性を もっていると考えられる.

\section{6. 結 語}

本研究によって得られた主な結果を要約すると，次の ようである.

（1）二次元海浜変形の実験における汀線移動量, berm 頂および砕波点の位置の各実験誤差は，沖波波形 勾配との関係で定量的に表示できた。これらの実験誤差 はその傾向がよく一致している．したがって，模型実験 の結果から現地海岸の予測を行う場合は，このような実 験誤差の重要性が指摘される.

（2）模型の初期海浜断面形状は，原型と幾何学的に 相似にし，波の諸特性を Froude 則で定め，底質の粒径 を式（6）の相似則で定めれば，海浜変形の再現実験が 可能である.すなわち，海浜変形の相似則としては， Froude 則によって波特性を規定した場合，漂砂を相似 にするためには式（6）で表わされるような Froude 則 によるものより粗く，かつ原型より若干細かい底質粒径 を用いればよいことになる。

（3）沖波波形勾配が $0.007 \leqq H_{0} / L_{0} \leqq 0.042$ の範囲 では, 海浜変形の相似則に及ぼす波形勾配の影響は非常 に少ない。

（4）式（6）の相似則は, 漂砂の移動限界水深に及 ぼす粘性効果を砂粒 Reynolds 数 $\left(u_{*} d / \nu\right)$, 境界層の 厚さで表わしたものや，海浜変形の特性を波と底質の Reynolds 数 $\left(\sqrt{g H_{0}} d / \nu\right)$ あるいは沈降速度などで表 示した式から求めた相似関係とその傾向がよく一致す る.

1) Beach Erosion Board : A study of comparative action of waves on model beaches of different scales, Bulletin, B. E. B., Vol. 1, No. 2, pp. 8 12, 1947.

2) Le Méhauté, B. : A comparison of fluvial and Coastal similitude, Proc. of 12th Coastal Engineering Conf., 
pp. 1077 1096, 1970.

3) Kamphuis, J. W. : Scale selection for mobile bed wave model, Proc. of 13th Coastal Engineering Conf., pp. 1173 1216, 1972.

4) Mogride, G. R. : Scale laws for bed forms in laboratory wave models, Proc. of 14th Coastal Engineering Conf. , pp. 1069 1085, 1974.

5) Saville, T. Jr. : Scale effects in two dimensional beach studies, Proc. 7th General Meeting, I. A.H.R., pp. A3. 1 8, 1957.

6）岩垣雄一・野田英明：海浜変形に及ぼす scale effect の研 究, 京都大学防災研究所年報, 第 14 号, pp. 210 220, 1961.

7) Paul, M. J., Kamphuis, J.W. and Brebner, A. : Similarity of equilibrium beach Profiles, Proc. 13th Conf. Coastal Engineering, pp.1217 1236, 1972.

8）出口一郎・椹木 亨：波浪による移動床実験の相似につ いて, 第 31 回年次学術講演会講演概要 II 部, pp. 1 2, 1976.

9) Dalrymble, R.A. and Thompson, W. W. : Study of equilibrium beach profiles, Proc. 15th Coastal Engineering Conf., pp. 1277 1296, 1976.

10) Noda, H. : Scale relations for equilibrium beach profiles, Proc. 16th Coastal Engineering Conf. pp. 1531 -1541, 1978.

11) Noda, E. K. : Equilibrium beach profile scale-model relationship, Jour. of the Waterways, Harbors and Coastal Engineering Div., ASCE, pp. 511 528, 1972.

12) Chesnutt, C. B. : Laboratory effects in beach studies, Analysis of results from 10 movable-bed experiments, U.S. Army Corps of Engineers, CERC, MR No. 77-7, 127 p. , 1978.

13) Smith, D. C., Herbich, J. B. and Spence, T. W. : Factors influencing equilibrium of a model sand beach, COE Report, No. 189, 83 p., 1976.

14）日本工業計測技術大系編集委員会編：工業計測概説／資 料, 日本工業新聞社, 1969 .

15) Watts, G. M. : Laboratory study of effects of varing wave periods on beach profiles, BEB, Technical Memo. No. 53, 19 p., 1954.

16）玉井佐一：海浜カスプの特性と海岸地形の変動予測に関 する研究, 京都大学学位論文, pp. 56 59, 1979.

17）堀川清司・砂村継夫・近藤浩右：波による二次元海浜変 形に関する実験的研究，第 21 回海岸工学講演会論文集, pp. 193 199, 1974.

18) Ozaki, A. : On the effect of an offshore breakwater on the maintenance of a harbor constructed on a sandy beach,
Proc. 9th Conf. Coastal Engineering, pp. 323 345, 1964.

19）佐藤昭二・田中則男・佐々木克博：清水港三保防波堤の 漂砂に関する実験的検討，港湾技術資料, No. 154, 31 p. 1973.

20）田中則男・小山内英雄：養浜工に関する研究（その 2 ) ——神戸市須麿海岸における人工海浜の安定に関する実 験およびその一般的考察—，港湾技研資料，No. 326， 50 p. , 1979.

21）土屋義人・伊藤政博：海浜変形の相似則に関する実験的 研究, 第 28 回海岸工学講演会論文集, pp. 315 319, 1981.

22）伊藤政博：二次元模型実験による現地海浜変形の再現性 に関する研究，第 29 回海岸工学講演会論文集, pp. 311 $\sim 315,1982$.

23）堀川清司・砂村継夫・近藤浩右・岡田 滋：波による二 次元汀線変化に関する一考察, 第 22 回海岸工学講演会論 文集，pp. 329 334，1975.

24）尾崎 晃・渡辺 摇：波による二次元汀線変化の相似則 に関する実験的研究, 第23回海岸講演会論文集, pp. 200 205, 1976.

25）伊藤政博・増田重臣：重回帰分析による二次元海浜変形 実験における汀線移動量の表示について，土木学会論文 報告集，第 321 号, pp. 91 101，1982.

26）佐藤昭二・田中則男：水平床における波による砂移動に ついて, 第 9 回海岸工学講演会講演集, pp. 95 100, 1962.

27）土木学会編：水理公式集，昭和 46 年改訂版, pp. 546 $548,1971$.

28）椹木 亨：移動床実験の現地海岸への適用に関する一考 察, 第 8 回海岸工学講演会講演集, pp. 134 138, 1961.

29) Johnson, J. W. : Scale effects in hydraulic models in volving wave action, Trans. Amer. Geophy. Union, Vol. 30, pp. $517 \sim 525,1949$.

30) Dean, R. G. : Heuristic models of sand transport in the surf zone, Conf. on the Engineering Dynamics in the Surf Zone, pp. 208 214, 1973.

31）服部昌太郎・川又良一：砕波帯内の海浜変形過程, 第 25 回海岸工学講演会論文集, pp. 218 222, 1978.

32) Rector, R. L. : Laboratory study of equilibrium profiles of beaches, BEB, Tech. Memo., No.41, 38 p. 1954.

33）鹿島遼一・清水隆夫 ·丸山康樹・斉藤昭三：大型造波水 路による岸沖漂砂の実験的研究, 第 28 回海岸工学講演会 論文集，pp. 197～201，1971.

34）佐藤昭二・左司忠夫・田中則男：仙台湾沿岸の漂砂につ いて, 第 13 回海岸工学講演会講演集. pp. 176 182, 1966.

35）鶴見一之：沈降速度の理論及び実験, 土木学会誌, 第 18 巻, 第 10 号, pp. 1059 1094, 1932.

(1984.7.14 - 受付) 